GENERAL ARTICLE

\title{
IIIness and social protection: an agenda for action in Sri Lanka
}

\author{
Saroj Jayasinghe \\ Department of Clinical Medicine, Faculty of Medicine, University of Colombo, Colombo 08
}

\begin{abstract}
Sri Lanka is facing demographic and epidemiological transitions. This demographic transition will result in the population of the elderly increasing rapidly over the next few decades. This group is likely to have a high prevalence of age-related chronic diseases and disabilities. The country also faces an epidemiological transition and the prevalence of Non Communicable Diseases (NCD)s is already showing signs of rapid increase in the young and the elderly. The provision of care for the chronically ill will increase costs of health care. This includes direct medical costs for treatment and direct non-medical costs such as transport costs to attend clinics. Indirect costs include loss of earnings as a result of illness and absenteeism and decreased productivity because of ill health. The state sector hospitals and clinics provide health care free at the point of delivery. However, studies indicate that households incur considerable out-of-pocket expenses during illness, partly because of transport costs and for accessing private healthcare. Costs incurred by households for specific illnesses indicate that the expenses can be several-fold of the average per capita income. Formal support for illnesses is limited and that too is through a multitude of institutions. The type of support provided is mostly limited to cash transfers and the linkages between social services and the health sector are weak. As a result, the health sector rarely interacts with the social services and therefore finds it tedious to direct the needy persons towards available social resources. Thus, households and families often carry the burden of chronic diseases and illness with little social support. With changing family structures (e.g. lesser number of children, migration of young adults and female employment), households will increasingly face difficulties in caring for the chronically ill. Comprehensive social policies are therefore essential to meet the growing needs of people with chronic illnesses. Formal linkages between the social service sector and the health sector are essential and can be increased by having cadres of medical social workers.
\end{abstract}

\section{INTRODUCTION}

Sri Lanka is facing demographic and epidemiological transitions. This demographic transition points to the population of elderly increasing rapidly over the next few decades. The population is expected to reach a maximum of 20 million by 2021 (low projection) or 23.2 million by 2046 (high projection) (De Silva, 2007). Those above 60 years will be almost $25 \%$ by 2041 . This group is likely to have a high prevalence of age-related diseases (e.g. non-communicable diseases (NCD) such as diabetes, hypertension, ischemic heart disease and stroke) and disabilities. The country also faces an epidemiological transition and the prevalence of NCDs is already showing signs of rapid increase in adults, including young adults (Katulanda, et al., 2008). A country-wide population survey found the age-sex standardized prevalence of diabetes for those aged 20 years or more to be $10.3 \%$ (males $9.8 \%$ and females 10.9\%). The projected prevalence of diabetes among those above 20 years was estimated to rise to $13.9 \%$ by 2030 . The high prevalence of NCDs impact the healthcare system in numerous ways and the estimated proportion of hospital admissions due to chronic NCDs (principally cardiovascular disease, diabetes, cancer, and asthma/chronic obstructive pulmonary disease) is $24 \%$ of total hospital admissions currently (Engelgan, Okomoto, Navaratne and Gopalan, 2010).

\section{ILLNESS AND BURDEN OF CARE}

The implications of demographic transition and increased prevalence of NCDs are numerous. There will clearly be human suffering and premature death. Furthermore, the provision of care for the chronically ill will require extra resources in the form of human resources, infrastructure, medical facilities and financial resources. The latter 
includes direct medical costs for treatment (e.g. drugs and investigations for patients with diabetes) and nonmedical direct costs such as transport costs to attend clinics. Indirect costs include loss of earning as a result of illness and absenteeism, and decreased productivity as a result of ill health. Theoretically, state sector hospitals and clinics should provide health care free at the point of delivery and therefore direct medical costs should have minimal impact on household expenditures. However, studies indicate that households incur considerable outof-pocket expenses during illness, partly because of transport costs and in accessing private healthcare. Even those attending state hospitals incur considerable hidden direct costs (for example to purchase drugs that are not available in the hospital) (Perera, Gunatilleke and Bird, 2007). Costs incurred by households for specific illnesses indicate that the expenses can be several fold of the percapita income.

One study reviewed the literature on three categories of illnesses and found considerable out-of-pocket expenditures among households in developing countries (Russel, 2004). The three diseases were: tuberculosis as an index of a chronic disease, HIV/AIDS as an example of a terminal illness and recurrent malaria as a form of illness with repeated episodes. Though the costs of illness (direct and indirect) for malaria were less than $10 \%$ of the total household income, it was significant when combined with the costs of other illnesses. In contrast, the costs of TB and HIV/AIDS were catastrophic for households and surpassed $10 \%$ of the total household income. The reasons for the high expenditures include, health service weaknesses, including low coverage, user charges, and poor quality of care (Russel, 2004). Studies on health costs in Sri Lanka indicate appreciable out-of-pocket expenses even with acute illnesses such as malaria. (Attanayake, Fox-Rushby and Mills, 2000). A study undertaken for the National Commission on Macroeconomics and Health Sri Lanka by Attanayake (2005), found that direct and indirect costs for outpatient care too, are considerably high. Almost 30\% of direct costs are borne by patients and $10 \%$ could not afford the treatment costs. It is reasonable to expect that these costs and adverse impacts will be worse with more severe illnesses requiring in-patient care.

As a result of the out-of-pocket expenses and indirect costs of healthcare, households can be pushed towards impoverishment. This process is termed the 'medical poverty trap', illustrating the potential for illnesses to perpetuate or worsen poverty at the household level (Perera, Gunatilleke and Bird, 2007). Though these effects are significant at a micro-level, Sri Lanka is placed favourably in the region and large-scale survey data on costs of illness and catastrophic costs at a household level indicate that the zero-charge health system has helped to cushion the impact of illness and prevent poverty.

\section{COPING WITH ILLNESS}

In Sri Lanka, there is only modest formal social support or protection for households to prevent them from falling into the 'medical poverty trap' (Perera, Gunatilleke and Bird, 2007). Instead, most households and families rely on informal networks of relatives and friends to bear the costs incurred by illness (Perera, Gunatilleke and Bird, 2007). The reason for this situation can be traced to features in the historical development of the social sector. It is argued that the fragmented system of social protection with a narrow range of provisions is a result of the state deliberately abdicating a part of its responsibility and burdening the informal sector to support the unemployed, the ill and the elderly (Jayasuriya, 2000). Forms of formal social support during illness are limited and that too is through a multitude of institutions (for example, cash transfers are available through the Samurdhi Authority, President's Fund and Ministries of Social Services at national and provincial levels). The type of support provided is mainly in the form of cash transfers and exceptions include the provision of wheel chairs for the differently-abled. Access to this fragmented support system is further compounded by a lack of formal institutional relationship between social services and the health sector. As a result, the health sector rarely interacts with the social services and therefore finds it tedious to direct needy persons towards available social resources. Social care in kind is mostly limited to institutional care for the elderly, such as Homes for the Elderly and Day-Care centers, with little provision for caring for the chronically ill or disabled. Social care in kind or through community based care givers (e.g. occupational therapists and physiotherapists who visit homes of chronically disabled) are almost non-existent.

\section{EMERGING CRISIS IN CARE}

There are several factors that could lead to a crisis in the provision of care for the ill, the differently-abled and the elderly in Sri Lanka. The first factor relates to increasing costs of health care, which may surpass increases in percapita income. Though the state is obligated to provide healthcare free at the point of delivery, patients and households continue to incur costs for transport and for other facilities, such as medicines and laboratory tests that 
are unavailable in the state sector (Perera, Gunatilleke and Bird, 2007; Attanayake, 2005). Furthermore, the increased involvement of the private sector in health care provision will further increase household costs on health. The second factor is the changing family structures in the context of a poorly funded formal social support sector. In the past few decades, the structure of families and households has demonstrated rapid changes due to lesser numbers of children, migration of young adults towards urban centers and employment of females who are the care givers in most households. These factors will lead to households facing increasing difficulties in caring for the chronically ill.

\section{CONCLUSION}

Sri Lanka faces a health transition that will lead to an increase in the numbers of chronically ill, the elderly, and those with severe disabilities. Currently these groups are supportedbyinformalsocialnetworksandfamilymembers. The status quo is likely to change with social and cultural changes, migration and the advent of nuclear families. In the absence of adequate social protection, the elderly, the ill and differently-abled have the potential to spiral into poverty. Urgent measures are therefore essential to tackle this impending crisis. Such measures could include strengthening of the welfare state, more comprehensive social policies, institutional changes and improved awareness of the public on available social resources.

\section{RECOMMENDATIONS FOR TACKLING THE EMERGING CRISIS IN SOCIAL PROTECTION}

Comprehensive social policies and programmes are essential to meet the growing needs of the elderly, differently-abled and those with chronic illnesses. Several recent initiatives augur well for Sri Lanka. These include the UN's Social Protection Floor Initiative and the role played by international organizations such as UNESCO, ILO and WHO. They may open a window of opportunity to establish comprehensive social protection in Sri Lanka (ILO and WHO, 2009). This paper proposes six thrust areas that may improve social protection of the ill, disabled and the elderly. They range from specific proposals relating to available programmes, to the very structure of the state.

a) Sri Lanka should develop better coordination among the numerous social welfare provider institutions and combine some of them to improve efficiency. Having several programmes or schemes or institutions to provide social support is inefficient and duplicates administrative work. For example, currently the Employment Trust Fund (which has provision to support permanently disabled private sector employees), the Employment Provident Fund (which provides similar support to ETF, to some of the state corporations, universities and institutions), Agrahara Health Insurance Scheme (for state officials), the President's Fund (for any citizen who needs assistance for selected health problems) and Samurdhi Programme (for poverty alleviation) function in different compartments under a range of Ministries, with little interaction or coordination among them. Similarly, there are several pension schemes (e.g. for farmers, self-employed persons, and fishermen) that are functioning with separate administrative structures. Sharing of information and improved linkages among these institutions will lead to a more cohesive and efficient programme of social support for the needy.

b) The coverage provided by these mechanisms also could be rationalized and widened. The President's Fund provides support for a few selected diseases (e.g. renal transplantation, coronary artery bypass, correction of scoliosis, certain cancers etc.) that appear to have been selected quite arbitrarily with little consultation or evaluation. For example, there is no support for preventive programmes such as provision of prophylactic clotting factors for Haemophiliac patients. Haemophiliac patients suffer bleeding episodes due to a birth defect, that leads to low circulating levels of proteins that initiate blood clotting. The bleeding episodes can be excruciatingly painful and the joints permanently damaged. In some instances, bleeding from vulnerable sites (e.g. from an ulcer in the stomach or from a wound) can lead to life threatening blood loss and death. All these episodes are prevented by giving proteins via an injection at regular intervals. This may appear costly, but it can prevent unimaginable suffering for patients and minimize cost of providing care when they bleed. Similarly, other health conditions where preventive action is important should also be identified and addressed.

c) The types of social support provided, needs to be diversified. Assistance for the ill and the elderly is often limited to cash transfers for hospital care or high-technology interventions, while the differentlyabled have additional provision for aids such as 
wheel chairs. Other options that could be included in the social protection package are: support for care givers to provide home based care of the chronically ill, provision of community based care for the chronically ill (e.g. occupational therapists foer wheel chair bound patients), hospice care for the terminally ill, institutional care for the severely ill (e.g. persons with dementia), home visits by persons to assist elderly who are living alone and institutional care for the elderly who are alone with no family or friends to support them. These interventions should strengthen the existing cultural practices of caring for the sick and form part of a larger social protection scheme for Sri Lanka that provides security to the needy.

d) A relatively neglected area of service provision is social work, which forms an important element of a welfare state (Chandraratne, 2008). Though there are several categories providing social support (e.g. Samurdhi officers), few have been formally trained in the discipline of social work. Furthermore, there are wide gaps in some areas of service provision, for example medical social work. The introduction of a cadre of medical social workers to liaise with the health personnel will be an important step to facilitate the provision of social care and support for the ill, the differently-abled and elderly. This should be done in conjunction with the development of closer links between the existing social support sector and the health system. Mechanisms should be in place for the health sector to refer appropriate persons to the social service sector. The paper-work to access such services too should be minimized in order to facilitate the process. Coupled with this, one would need to increase awareness of the health professionals and the general public regarding the availability of these services for the needy.

e) Increasing awareness of available social resources should include the compilation of a register of service providers and its wide dissemination among the public and health care institutions. The potential providers should include the non-governmental sector and community based organizations (CBOs). This awareness raising could begin at the level of the undergraduate curriculum so that future professionals will be sensitized. (The Faculty of Medicine in Colombo has introduced these concepts in its Social Paediatrics programme in Community Medicine and the Social Medicine programme in Clinical Medicine). These could be taken as examples for training programmes of other health personnel and by other universities. f) Research shows favorable social policies are more likely within a welfare state, where the state is the key player in protecting and promoting the economic and social wellbeing of its citizens, often using mechanisms such as social insurance (Navarro et al., 2003; 2006). This will require working towards the strengthening of the welfare state using newer concepts such as citizenship and 'third way' politics (Jayasuriya, 2010). These approaches attempt to modify the traditional welfare states by finding middle ground between the top-down socialist control of the economy and the capitalist market-based approaches to economic governance. Instead, it favours entrepreneurship, economic growth and wealth creation, but also sees a major role for the state to promote or ensure social justice. In order to initiate such changes, one has to enter the political arena and introduce amendments to the Constitution, that would transform or modify the very structure of the state, ensuring more allocations are made for social welfare that would lead to the establishment of a comprehensive social welfare system to support the unemployed, the ill, the elderly and the differently-abled.

\section{References}

1. Attanayake, N., Fox-Rushby, J. \& Mills A., 2000. Household costs of 'malaria' morbidity: a study in Matale district, Sri Lanka. Tropical Medicine and International Health, 5, pp. 595-606.

2. Attanayake, N., 2005. The economic costs of five common diseases in Sri Lanka. Study Report 2. Colombo: The National Commission on Macroeconomic and Health, Sri Lanka.

3. Chandraratne, D., 2008. Social Work Education and Practice: A Sri Lankan perspective. Colombo: Vijitha Yapa Publications.

4. Doorslaer,V. et al., 2006. Effect of payments for health care on poverty estimates in 11 countries in Asia: an analysis of household survey data. Lancet, 368, pp. 1357-64.

5. De Silva, W. I., 2007. Beyond Twenty Million: Projecting the population of Sri Lanka 2001-2081. Colombo: Institute of Policy Studies.

6. Engelgau, M., Okamoto, K., Navaratne, K.V. \& Gopalan, S., 2010. Prevention and Control of Selected Chronic NCDs in Sri Lanka: Policy Options and Action. HNP Discussion Paper. Washington: The World Bank. 
7. International Labour Office \& World Health Organisation, 2009. The Social Protection Floor: A Joint Crisis Initiative of the UN Chief Executives Board for Co-ordination on the Social Protection Floor. [Online] Available at: <http://www.un.org/en/ $\mathrm{ga} /$ second/64/socialprotection.pdf $>$ [Accessed on 15 November 2010]

8. Jayasuriya, L., 2000. Welfarism and politics in Sri Lanka: experience of a third world welfare state. Australia: University of Western Australia.

9. Jayasuriya, L., 2010. Taking Social Development Seriously: The experience of Sri Lanka. New Delhi: Sage Publications.

10.Katulanda, P. et al., 2008. Prevalence and projections of diabetes and pre-diabetes in adults in Sri LankaSri Lanka Diabetes, Cardiovascular Study (SLDCS). Diabetic Medicine,25, pp. 1062 - 69.
11. Navarro, V. et al., 2003. The importance of the political and the social in explaining mortality differentials among the countries of the OECD, 1950 to 1998. International Journal of Health Services Research, 33, pp.419-494.

12. Navarro, V. et al., 2006. Politics and health outcomes. Lancet, 368, pp.1033- 37.

13.Perera, M., Gunatilleke, G. \& Bird, P., 2007. Falling into the Medical Poverty Trap in Sri Lanka: What Can Be Done? International Journal of Health Services, 37 , pp. $379-98$.

14. Russell, S., 2004. The economic burden of illness for households in developing countries: A review of studies founding on Malaria, Tuberculosis, and human immunodeficiency virus/acquired immunodeficiency syndrome. American Journal of Tropical Medicine and Hygiene, 71 (supplement 2), pp.147- 55. 